\section{Getting Started with Graphic Novels}

\section{A Guide for the Beginner}

Correspondence concerning this

column should be addressed to

Neal Wyatt, Collection Management Senior Librarian, Chesterfield County

Public Library, 9501 Lori Road,

Chesterfield, VA 23832; e-mail:

wyattn@chesterfield.gov.

\section{Anne Behler is a Reference Librarian at The Pennsylvania State University, University Park.}

Graphic novels are an incredibly popular format in all types of libraries. Popular movies such as Batman, Spider-Man, $V$ for Vendetta, and Sin City are all based on graphic novels or comics and underscore the growing appreciation for the medium. Readers are leading the way, demanding these titles and teaching us the joys of the graphic form. Yet despite our patrons' call for these items in our collections, it is often hard to know what to buy, what is useful and popular in a sea of seemingly odd titles and collections, and how to approach the question of suitability and classification. An academic librarian undertaking a collection-building effort at her university wrote this Alert Collector column. The fact that academic librarians are paying attention to the form simply strengthens the argument that this particular type of reading experience has far exceeded its day as a boyhood pastime (if indeed that perception was ever true).

Anne Behler is a reference librarian at The Pennsylvania State University who works in the Maps and Gateway Libraries specifically, and in the instructional programs department (which runs the services of the library that are geared primarily toward meeting undergraduate and first-time user needs). She is the selector in charge of contemporary topics, which led her to developing Penn State's graphic novel collection. Demonstrating her commitment to student outreach, she is the co-chair of the libraries' annual open house, an event that welcomes more than four thousand students to the libraries each year, and is involved in the library's pilot effort at providing remote reference services in the university's student union building (the HUB). She is an active member of the ALA and the Reference and User Services Association (RUSA), serving on the Reference Services Section's Education and Professional Development for Reference Committee, as well as serving as intern for the RUSA Thomson Gale Award for Excellence in Reference and Adult Services Committee.-Editor.

\footnotetext{
he graphic novel format, like all forms of narrative, includes many different types of stories. For example, the superhero story is intriguingly told in Mark Waid's Kingdom Come. In this graphic novel, a slew of well-known DC Comic superheroes, such as Superman, Wonder Woman, and Batman, confront the challenges of their new generation, and not so moral, successors. The teen-interest novel, those sly and moody books that explore the angst of approaching adulthood, finds particularly rich expression in the graphic format, as exemplified by Ghost World by Daniel Clowes. Satire is also a common form, best represented by Robert Crumb's work. Takehiko Inoue's Vagabond is an excellent introduction to manga, which is an
} 
extension of Japanese anime and an art form in and of itself. These works often have strong appeal with teenage girls, proving yet again that stereotypes of the format are pointless. Graphic works include nonfiction as well and cover such topics as true crime, history, science, biography, and memoir. A good example of this is the stellar work Mom's Cancer by Brian Fies, which poignantly captures the story of his mother's battle with lung cancer. Finally, adaptations such as Jerry Bingham's Beowulf take well-known stories and recreate them in a graphic format, making accessible to some readers works that would otherwise be off-putting. This rich range of reading choices not only answers our patrons' calls for titles, it adds a richness and depth to our collections and helps encourage a love of reading.

The graphic novel represents a format that has come into its own in the last three decades. In the words of Will Eisner, the man credited with writing the first graphic novel and coining the term for the format, "The manner of [comics] creation has evolved from a work written and drawn by a single individual to a wedding between writer and artist. This has established a creative process that employs the skills of an accomplished writer and an artist of great sophistication." With roots in the serial comic strip, during the 1970s and ' 80 s, comics began to take on a more literary tone; many publishers moved away from the serial publication of short comic books to focus on more complex book-length titles, and as a result, comic readership expanded from children to young adults and adults, who found their preferred format maturing along with them. The move away from serial titles also meant that the desired book would much more likely be in stock in bookstores rather than solely available (and often sold out) at the local comic shop. ${ }^{2}$

The evolution of comics from Sunday-morning strips to comic books to graphic novels- "book-length comic books that are meant to be read as one story"-has drawn much critical attention. ${ }^{3}$ Several titles have won prestigious book awards, beginning with Art Spiegelman's Maus, which won the 1992 Pulitzer Prize. Widely read review sources like the New York Times Book Review have published articles on graphic novels, including "Draw What You Know: Graphic Novels Are Never Dull-Try Saying that About Most Works of Prose Fiction," in which writer Nick Hornby relates (when comparing his pile of "proper books" to his pile of comic books) "[C]omic books are never dull, in the excruciating way that prose fiction can be, and it's as hard to imagine half-reading most graphic novels . . . as it is to imagine halfreading a sonnet." ${ }^{\prime 4}$

The graphic novel's rise in popularity and sophistication has also grabbed the education community's attention. Educators recognize that today's students are constantly visually stimulated by the media and have a strong impatience for sitting down and wading through dense text. Graphic novels cater to young people's growing affinity for the visual rather than written media. ${ }^{5}$ It is no wonder, then, that graphic novels are often cited as wonderful tools to help get the "reluctant reader" into books. Gretchen Schwarz has pointed out that, in addition, graphic novels provide readers with the opportunity to learn about literature they might otherwise never encounter (through adaptations), as well as to critique the way visual portrayals create meaning. ${ }^{6}$ It is clear that graphic novels engage readers, and in fact, studies have shown that graphic novels make useful literacy tools as well, exposing readers to twice as many words as the average children's book. ${ }^{7}$

There is also little doubt that graphic novels are extremely popular with readers. The combined educational value and high appeal of graphic novels make them an essential asset to any library collection. Therefore it is extremely important for librarians to become familiar with the many incarnations of the graphic novel, in order to build the best collection possible to serve our patrons.

The resources presented in this column are meant to serve as a starting point for selectors working with graphic novels and will provide background information on the format as well as recommended selection tools. A listing of graphic novels that selectors should consider when building a core collection for any library is also included. This list is not comprehensive and is—like any other list—admittedly subjective. It includes titles that have been recognized for their significant contributions to the world of graphic novels; it has been compiled to form a solid foundation for anyone interested in learning more about this exciting area of literature. I highly recommend that newcomers to graphic novels read these core titles to get a sense of the form as well as to enjoy both serious literary, artistic endeavors and pure reading pleasure.

\section{BACKGROUND INFORMATION ON GRAPHIC NOVELS}

Gravett, Paul. Graphic Novels: Everything You Need to Know. New York: Collins Design, 2005. (ISBN: 0-06-082425-5)

Paul Gravett presents an in-depth look at many of the graphic novels that could be considered core titles. This text intermingles graphic novel history and analysis of titles, with colorful excerpts from the highlighted texts to create a work that is useful for the graphic novels neophyte and the long-time reader. The section titled "Resources" is especially helpful. It presents a bibliography of publishers' Web sites, suggested further readings about graphic novels, review sources, and more.

McCloud, Scott. Understanding Comics: The Invisible Art. Edited by Mark Martin. New York: Paradox Pr., 2000. (ISBN: 1-56389-557-9)

This text is a reference source that reveals the inner workings of the comic format by using the format itself. Artist Scott McCloud uses a book-length comic to illustrate the complex artistic elements and creative process that distinguish the comic format from all others. Readers are trained in vocabulary as well as how to follow the sequence of a comic work. McCloud's reverence for the elevation of art that comics can achieve is apparent on every page, creating a text that is effective in helping the novice comics reader to not only understand 


\section{THE ALERT COLLECTOR}

how to approach the reading of the medium, but to appreciate comics as a literary and artistic form as well.

Robbins, Trina. From Girls to Grrrlz: A History of Comics from Teens to Zines. San Francisco: Chronicle Bks., 1999. (ISBN: 0-8118-2199-4)

Graphic novels and comic books are often perceived as a male-centered format. Trina Robbins's book proves that this has not always been so. From Girls to Grrlz traces the history of girls' comics from the 1940s to the 1990s and presents readers with several titles that should be considered when building a graphic novel collection meant to appeal to both genders. As with many titles that relate graphic novels history, Robbins's takes the form of an annotated bibliography intermingled with historical details. This is a form that works particularly well for the beginner selector, as it allows one to review a foundational list of titles while developing an understanding of the history and culture surrounding the format.

Sabin, Roger. Comics, Comix, and Graphic Novels: A History of Comic Art. London: Phaidon Pr., 1996. (ISBN: 0-71483993-0)

Roger Sabin's bountifully illustrated history of comics is noteworthy because it reaches back to the very beginnings of comic-like creation with its examination of art forms since the Middle Ages. This text is also unique because it examines the format's history in both the United States and Britain.

Weiner, Stephen. Faster than a Speeding Bullet: The Rise of the Graphic Novel. New York: Nantier Beall Minoustchine, 2003.

(ISBN: 1-56163-367-4)

Weiner skillfully presents the history and development of the comic, from the birth of the very first comic strips in the early 1900s to the graphic novels of the present, using language and structure that makes the complex history easy to understand for those new to the format. The work is structured so that each chapter covers roughly a decade in the history of comics, and Weiner gives not only raw historical facts but presents analysis that helps the reader to understand the core reasons for the evolution of comics into the graphic novel. The book also highlights comic and graphic novel titles and authors who have come to represent the changes in the comics format as well as suggestions for further reading, in effect helping the reader to create a core list for him or herself.

\section{RESOURCES ADDRESSED TO LIBRARIANS}

Goldsmith, Francisca. Graphic Novels Now: Building, Managing, and Marketing a Dynamic Collection. Chicago: ALA, 2005. (ISBN: 0-8389-0904-3)

Graphic Novels Now is the perfect handbook for a librarian starting a graphic novel collection. After giving a brief overview of the graphic novel format and its history, Goldsmith provides selectors with the tools they will need to get started-recommended review sources, collection-maintenance suggestions, cataloging advice, marketing and programming suggestions, and even advice on how to handle the politics associated with graphic novels. Much of Goldsmith's advice is drawn from her own experiences with trying to start a graphic novel collection in a public library; the text takes a slight angle toward public libraries, but would serve as a wonderful tool for academic and school librarians as well.

Weiner, Stephen. The 101 Best Graphic Novels. Edited by Keith R. A. DeCandido. New York: Nantier Beall Minoustchine, 2001. (ISBN: 1-56163-284-8)

Stephen Weiner, a librarian and leading graphic novels specialist, presents an annotated list of 101 graphic novels that he considers to be the best. Of course, no list can be considered definitive forever, and new titles are published every day, but Weiner's titles are carefully chosen and his annotations keep in mind the appeal of the book to different types of readers. Librarians might use the list to assess their own library's graphic novel collection or as a foundation for building new collections. As is usual of Weiner publications, this guide also includes a brief history of graphic novels, as well as an appendix of suggested further readings about the format.

\section{SELECTORS'TOOLS}

\section{Bibliographies and Lists}

Rothschild, D. Aviva. Graphic Novels: A Bibliographic Guide to Book-Length Comics. Englewood, Colo.: Libraries Unlimited, 1995. (ISBN: 1-56308-086-9)

Aviva Rothschild's bibliography is proof of the complexity and variety of theme that exists within the graphic novel format. Rothschild's annotations are thorough and helpful and range in category from adaptations of classics to superheroes to Westerns.

YALSA's Great Graphic Novels for Teens list.

This list will make its publication debut at ALA's 2007 Midwinter Meeting. Title nominations thus far can be viewed, or a nomination can be made, at www.ala.org/ala/yalsa/book listsawards/greatgraphicnovelsforteens/gn.htm. This listing can give librarians a sense of what fans of the format find exemplary and will help them gain ideas for collection building.

\section{Journals}

Booklist. Chicago: ALA, 1905-. Bimonthly. (ISSN: 0006-7385)

Booklist is an ALA publication that regularly reviews graphic novels. Librarians review the titles, with an eye to collection building and make recommendations based on the titles' level of interest to libraries. In addition, Booklist annually dedicates one issue solely to graphic novels that is a must-read event for anyone interested in the format.

The Comics Journal. Seattle: Fantagraphics Bks: 1977-. Monthly (ISSN: 0194-7869) 
The Comics Journal is published by Fantagraphics Books, a leading publisher of comics and graphic novels. The journal focuses on comics and graphic novels as an art form, and regularly presents reviews. The latest issue's table of contents is available on the journal's home page at www.tcj.com, and it includes active links to excerpts of a few of the articles. A full-text online archive of the journal is also available through the Web site, but the newest issues posted are typically about five years old.

Library Journal. New York: Reed Business Information: 1876-. Semimonthly, monthly July/Aug. (ISSN: 0363-0277)

Library Journal regularly covers graphic novels, in both articles and reviews. Look for Steve Raiteri's regular column-it is a great resource for librarians building collections or serving patrons interested in the format.

School Library Journal. New York: Reed Business Information: 1954-. Monthly. (ISSN: 0362-8930)

As its name implies, School Library Journal (SLJ) is geared towards librarians working in school libraries; however, its articles and reviews often apply to the broader audience of children's and young adult librarians as well as to anyone interested in the subject matter discussed. As part of its regularly published reviews, SLJ often includes graphic novels that are appropriate for juvenile to high school readers.

Voice of Youth Advocates (VOYA). Metuchen, N.J.: Scarecrow Pr., 1978-. Bimonthly. (ISSN: 0160-4201)

Kat Kan writes a regular graphic novels column for VOYA. The journal also publishes an occasional review on the format.

Kirkus Reviews. New York: VNU Business Pubs., 1933-. Monthly. (ISSN: 0042-6598)

Kirkus Reviews publishes an annual special edition reviewing graphic novels that have come out during that year. The 2006 edition is available in full-text online at www.kirkus reviews.com/kirkusreviews/images/pdf/Kirkus_GraphicSpot _7.06.pdf.

\section{Web sites}

No Flying, No Tights: A Web Site Reviewing Graphic Novels for Teens, www.noflyingnotights.com/lair/index.html

No Flying, No Tights offers reviews of graphic novels by genre. While the site is geared primarily toward teen readers, it also offers a collection of core lists for librarians and educators and the reviews are well written and helpful for selection.

Recommended Graphic Novels for Public Libraries, http:// my.voyager.net/ sraiteri/graphicnovels.htm

Steve Raiteri, well-respected graphic novels columnist for Library Journal, presents a selective annotated list of titles he recommends. The list is divided into categories and stresses superhero and Japanese titles. In addition, Raiteri presents a list titled "Opening Collection," which suggests thirty titles libraries should consider when beginning a graphic novels collection.

Graphic Novels for Libraries, www.angelfire.com/comics/ gnlib/index.html (GNLIB-L)

This Web site offers subscription to GNLIB-L, a discussion list dedicated to the graphic novels topic; many members are librarians. In addition, the site includes a list of Web sites that can serve as collection development resources.

A Librarian's Guide to Anime and Manga, www.koyagi.com/ Libguide.html

This Web site is an extremely thorough guide to the anime and manga formats. Not only does the site offer lists of recommended titles; it also lists good review sources, special considerations librarians should make when purchasing manga, as well as background information, and a brief history of each format.

\section{CORE GRAPHIC NOVEL TITLES}

9-11: Artists Respond. Vol.1. Milwaukie, Ore.: Dark Horse Comics, 2002. (ISBN: 1-56389-881-0)

This title represents a collaboration of more than one hundred artists-it is a wonderful way to become familiar with the artistic styles of many well- and lesser-known graphic novelists. It is composed of vignettes and stories that communicate both the events of September 11, 2001, and the artists' reactions and feelings about those events.

Brabner, Joyce, and Harvey Pekar. Our Cancer Year. New York: Four Walls Eight Windows, 1994. (ISBN: 1-5658-011-8)

Harvey Pekar is known for his portrayals of the reality of everyday life. In Our Cancer Year, he and his wife relate the story of Pekar's own battle with cancer. Frank Stack, who lived with the couple during much of Pekar's sickness, illustrates the story. Our Cancer Year is real and honest, both in word and illustration, drawing the reader into a story of fear and pain, but also of love and hope.

Briggs, Raymond. When the Wind Blows. New York: Schocken Bks., 1982. (ISBN: 0-80523-829-8)

Briggs's graphic novel is a simple story with enormous impact as a satirical tragedy. It takes place in the 1980s, during the Cold War. Great Britain, home to characters Jim and Hilda Bloggs, is under nuclear attack. Jim and Hilda find comfort in the governmental "Powers that Be" and follow the official instructions to return to "life as normal" after the attack. Sadly, though Jim and Hilda try their best to get on with life, no one ever comes to help them, life does not return to normal, and they slowly begin to die of radiation poisoning. This powerful story raises questions about the reasons for war and the mechanisms that the government uses to gain people's trust-and what that trust might do to the people in the end. 


\section{THE ALERT COLLECTOR}

Eisner, Will. A Contract with God and Other Tenement Stories. New York: DC Comics, 1996. (ISBN: 1-56389-674-5)

Will Eisner's seminal work is a must-read for anyone who wants to understand the inspiration for and roots of the graphic novel format. A Contract with God and Other Tenement Stories is often credited as the first graphic novel and is the work that led Eisner to coin the term. While the graphic novel art form has evolved since this title's first printing in 1978, this is a key text to own. In Contract, Eisner did more than experiment with a medium; his vividly honest stories of Jewish tenement life laid a firm foundation for the revolution that has resulted in the recognition of graphic novels as a literary form.

Gonick, Larry. The Cartoon History of the Universe Volumes 1-7. New York: Broadway Bks., 1990. (ISBN: 0-38526-520-4)

The Cartoon History of the Universe Volumes 1-7 (which has since been followed by volumes 8-13), relates the history of the world, starting with the Big Bang, and following through to the beginnings of human civilization. By combining the cartoon medium with historical facts, Gonick was able to create a work that is both humorous and educational.

Introducing series. Cambridge, U.K.: Icon Bks.

The Introducing series is a collection of more than fifty volumes, each covering one of many nonfiction topics. Each volume is written by an expert and is illustrated by a known graphic artist. This series is unique in that it can serve as an instructional and reference tool. The text tends to take a formal tone, rather than a narrative story, and topics covered range from Chomsky to Einstein, anthropology to semiotics. The text and illustrations work well together to offer an introductory, yet thorough, treatment of each topic.

Kubert, Joe. Fax From Sarajevo: A Story of Survival. Milwaukie, Ore.: Dark Horse Books, 1996. (ISBN: 1-56971-143-7)

In Fax From Sarajevo, Joe Kubert tells the true story of his correspondence with his friend Ervin Rustemagic during the early 1990s. Rustemagic moved home to Sarajevo in 1992, during a period of two and a half years he sent faxes to Kubert, relating the bombing and destruction of his home city. Kubert's novel is well crafted and visually compelling. He intersperses photocopies of the faxes between cartoon sequences and sandwiches the cartoons between prose and photographic pieces-all of which vividly show the reader the reality of the war.

Satrapi, Marjane. Persepolis: The Story of a Childhood. New York: Pantheon Bks., 2003. (ISBN: 0-375-71457-X)

In Persepolis, Satrapi brings many of the issues surrounding Middle East conflicts into focus as she relates the story of her childhood in Iran during the Islamic Revolution and the Iran-Iraq war. Even as a child, Satrapi was extremely politically aware, and this awareness, conveyed in the frank language of children, forces the reader to take notice of the human tragedies that have occurred in Iran. Her simple but clear drawings beautifully complement her story.
Spiegelman, Art. Maus: A Survivor's Tale. 2 vols. New York: Pantheon Bks., 1986-1991. (ISBNs: 3-94541-55-3 and 067972-77-1)

Art Spiegelman's Maus, broken into two volumes entitled My Father Bleeds History and And Here My Troubles Began, is perhaps one of the most recognized graphic novels ever published. Spiegelman relates the true story of his father's life as a Polish Jew who was sent to Auschwitz in such a way that readers feel and begin to process the horror that was the Holocaust. If you want to begin to understand the potential power that lies within the graphic novel format, read Maus.

Thompson, Craig. Blankets. Marietta, Ga.: Top Shelf Productions, 2004. (ISBN: 1-891830-43-0)

Blankets is a 582-page story that is impossible to put down. Author and artist Craig Thompson portrays his own coming-of-age story. Thompson grew up in Wisconsin, the child of fundamentalist Christian parents. Painful episodes of his childhood-bullying at school and abuse from adults-intermingle with memories of sharing his bed and blankets with his younger brother, playing in the snow, and going away to annual church camp during the winter holiday. Thompson's illustrations give the stories a dream-like quality, reinforcing his jumbled recollections of childhood. As Thompson grows up, he trades in the blankets he shared with his brother for a blanket shared with a lover, and he struggles to define his own relationship with God and his place in the world. Thompson turns himself inside out on the pages of this graphic novel, and his story is brought vividly to life by his illustrations.

\section{OTHER KEY TITLES TO CONSIDER}

B., David. Epileptic. New York: Pantheon Bks., 2005. (ISBN: 0-37542-318-4)

Briggs, Raymond. The Snowman. New York: Random House, 1978. (ISBN: 0-39483-973-0)

Callahan, Bob, ed. The New Comics Anthology. New York: Collier Bks., 1991. (ISBN: 0-02009-361-6)

Feiffer, Jules. Tantrum. New York: Knopf, 1979. (ISBN: 0-39450-837-8)

Gaiman, Neil. The Sandman: Preludes and Nocturnes. New York: DC Comics, 1995. (ISBN: 1-56389-011-9)

Laird, Roland Owen Jr., and Taneshia Nash Laird. Still I Rise: A Cartoon History of African Americans. New York: Norton, 1997. (ISBN: 0-39304-538-2)

Miller, Frank. Sin City. Milwaukie, Ore.: Dark Horse Bks., 2005- . (various ISBN's)

Frank Miller with Klaus Janson and Lynn Varley. Batman: The Dark Knight Returns. 10th anniversary ed. New York: DC Comics, 1996. (ISBN: 1-56389-342-8)

Moore, Alan. V for Vendetta. New York: DC Comics, 1989. (ISBN: 0-93028-952-8)

Sacco, Joe. The Fixer. Montreal: Drawn and Quarterly, 2003. (ISBN: 1-89659-760-2) 
Sacco, Joe. Palestine. Seattle: Fantagraphic Bks., 2001. (ISBN: 1-56097-432-X)

Simmonds, Posy. Gemma Bovery. New York: Pantheon Bks., 2004. (ISBN: 0-37542-339-7)

\section{References}

1. Will Eisner, foreword to Faster than a Speeding Bullet: The Rise of the Graphic Novel by Stephen Weiner (New York: Nantier Beall Minoustchine, 2003), ix.

2. Stephen Weiner, The 101 Best Graphic Novels, ed. Keith R. A. DeCandido (New York: Nantier Beall Minoustchine, 2001), $14-15$.
3. Stephen Weiner, Faster than a Speeding Bullet: The Rise of the Graphic Novel (New York: Nantier Beall Minoustchine, 2003), xi.

4. Nick Hornby, "Draw What you Know: Graphic Novels are Never Dull-Try Saying that About Most Works of Prose Fiction," New York Times Book Review 27 (Dec. 22, 2002): 10.

5. Katherine T. Bucher and M. Lee Manning, "Bringing Graphic Novels into a School's Curriculum," Clearing House 78, no. 2 (Nov./Dec. 2004): 67.

6. Gretchen E. Schwarz, "Graphic Novels for Multiple Literacies," Journal of Adolescent \& Adult Literacy 46, no. 3 (Nov. 2002): 262-63.

7. Weiner, Faster than a Speeding Bullet, 61. 